\title{
MICROPROPAGATION OF DATE PALM CV. MALAKABY THROUGH SOMATIC EMBRYOGENESIS \\ 2- EFFECT OF ADENINE HEMISULFATE, GLUTAMINE AND GLUTATHIONE
}

Hegazy, A.; M. I. Nasr; I. A. Ibrahim and H. H. El-Bastawissy

Genetic Engineering and Biotechnology Research Institute (GEBRI), Plant Biotech. Department., Minufiya University, Sadat City, Egypt

\begin{abstract}
Addition of chemical compounds (adenine hemisulfate glutamine or glutathione) to the culture medium of date palm (Phoenix dactylifera. L.) dry cultivar, i.e. Malakaby affected positively repetitive somatic embryos cycle, plantlets formation and subsequently acclimatization as compared with the control.

Repetitive somatic embryos cultured on modified MS medium (MMS) supplemented with NAA $0.1 \mathrm{mg} / \mathrm{l}$, Kin $0.5 \mathrm{mg} / \mathrm{l}$ and activated charcoal $1.5 \mathrm{~g} / \mathrm{l}$ in addition to adenine hemisulfate at the concentration of $40 \mathrm{mg} / \mathrm{l}$ and solidified with gelrite $1.5 \mathrm{~g} / \mathrm{l}$ recorded the highest no. of embryos, multiplication rate, fresh weight and growth value after 3 weeks of culture incubation. However, glutamine at the concentration of $200 \mathrm{mg} / \mathrm{l}$ recorded higher embryos multiplication rate, fresh weight and growth value. On the other hand, glutathione at the concentration of $15 \mathrm{mg} / \mathrm{l}$ recorded higher significant values of no. of embryos and embryos multiplication rate as well as higher fresh weight and growth value.

Resulted shootlets were cultured individually on MS basal medium supplemented with NAA $0.5 \mathrm{mg} / \mathrm{l}$ and IBA $0.5 \mathrm{mg} / \mathrm{l}$ in addition to the same chemical compounds concentrations previously tested and solidified with $6 \mathrm{~g} / \mathrm{l}$ phyto agar. Wellrooted plantlets obtained were transferred ex vitro for acclimatization on soil type mixture of compost and perlite $(1: 1 \mathrm{v} / \mathrm{v})$.

Addition of adenine hemisulfate $(40 \mathrm{mg} / \mathrm{l})$ or glutamine $(100 \mathrm{mg} / \mathrm{l})$ to the rooting medium recorded the highest growth value and no. of leaves respectively as well as the highest no. of roots after 8 weeks of culture incubation and raised the same values of plantlets survival $(13.33 \%)$ over the control after 3 months in acclimatization. However, addition of glutathione at the concentration of $15 \mathrm{mg} / \mathrm{l}$ to the rooting medium recorded higher values of no. of leaves, fresh weight, no. of roots and raised plantlets survival (20\%) over the control in acclimatization.
\end{abstract}

Keywords: Phoenix dactylifera L., in vitro, embryogenesis, callus, chemical compounds.

\section{INTRODUCTION}

Date Palm (Phoenix dactylifera L.) is one of the most important fruit crop in Egypt. The use of rapid propagation of date palm through tissue culture is the most promising technique for production of sufficient plant materials with high quality. The major obstacles to the practical application of date palm tissue culture to mass propagation have been in the reduction of survival rate during acclimatization under greenhouse or field condition. Substantial numbers of micropropagated plants do not survive after transfer from in vitro conditions to greenhouse or field environments. This was depending primarily upon the quality and type of materials produced in the previous stages (Hegazy et al., 2006). Amino acids and amides can be added 
Hegazy, A. et al.

to plant media to satisfy the requirement of cultures for reduced nitrogen (Nickell and Maretzski (1969). Most of the inorganic nitrogen supplied in culture media is converted by plant tissues to amino acids, which are then assimilated into proteins; it should be possible to culture plants on media on in which amino acids are the only nitrogen source. Amino acids provide plant cells with an immediately available source of nitrogen, and uptake can be much more rapid than that of inorganic nitrogen in the same medium (George, 1993). Organic nitrogen was considered as a growth-limiting factor in date palm cultures (Abo El-Nil, 1986). The explants cultured with other nitrogen sources resulted in low culture frequency and low number of shoots per explant accompanied by basal callusing and necrosis (Vasudevan et al., 2004). Hegazy (1992) reported that beneficial effect were obtained in explant growth and shoot proliferation of Strelitizia reginae Ait in the presence of adenine sulphate $(80 \mathrm{mg} / \mathrm{l})$ in MS medium. Kaur et al. (1998) found in Acacia catechu explant that addition of adenine sulphate $(25.0 \mathrm{mg} / \mathrm{l})$, ascorbic acid $(20.0 \mathrm{mg} / \mathrm{l})$ and glutamine $(150.0 \mathrm{mg} / \mathrm{l})$ to the culture medium obtained maximum shoot bud induction. Glutamine appears as a suitable nitrogen source to support the active protein synthesis associated with somatic embryo maturation (Milfin and Lea, 1976). Modified MS medium inclusion glutamine at the concentration of $200 \mathrm{mg} / \mathrm{l}$ enhanced repetitive somatic embryos and shoots development of date palm cvs Zaghloul and Barhi Hegazy (2003). Belmonte et al. (2005) reported that exogenous applications of reduced glutathione (GSH) and oxidized glutathione (GSSG) promote growth of embryogenic tissue of white spruce during a 7-day subculture period.

The aim of this work was to study the influence of some chemical compounds i.e. Adenine hemisulfate, glutamine and glutathione concentrations on date palm (Phoenix dactylifera. L.) dry cultivar, i.e. Malakaby during repetitive somatic embryos cycle, plantlets formation and subsequently their effects on plantlets survival percentage during acclimatization.

\section{MATERIALS AND METHODS}

This work was carried out in the Plant Tissue Culture Laboratory, Plant Biotechnology Department of the Genetic Engineering and Biotechnology Research Institute (GEBRI), Sadat City, Minufiya University Egypt, during the period 2005-2008.

The present work was carried out to study the influence of some chemical compounds i.e. Adenine hemisulfate, glutamine and glutathione on date palm (Phoenix dactylifera. L.) dry cultivar, i.e. Malakaby during micropropagation stages:

A- Repetitive somatic embryos cycle.

B- Plantlets formation and acclimatization.

Plant materials:

In this work, regenerated somatic embryos of cv. Malakaby, obtained during the first part of this work (Nasr et al., 2008) were utilized.

Medium composition: 
The regenerated embryos clusters were cultured on MS (Murashige and Skooge, 1962) modified medium (MMS). The MMS medium (Nasr et al., 2008), with the modification of such nutrients concentrations, i.e. asparagen $(100 \mathrm{mg} / \mathrm{l})$, bioten $(0.5 \mathrm{mg} / \mathrm{l})$, thiamine- $\mathrm{HCl}(5 \mathrm{mg} / \mathrm{l})$, Ca-pantothenate $(2.5$ $\mathrm{mg} / \mathrm{l})$, a ascorbic acid $(75 \mathrm{mg} / \mathrm{l})$, citric acid $(75 \mathrm{mg} / \mathrm{l})$, polyvinylpyrrolidone (1.5 $\mathrm{g} / \mathrm{l})$, NaH2PO4. 2H2O (170 mg/l asparagen $(100 \mathrm{mg} / \mathrm{l})$, bioten $(0.5 \mathrm{mg} / \mathrm{l})$, thiamine- $\mathrm{HCl}(5 \mathrm{mg} / \mathrm{l})$, Ca-pantothenate $(2.5 \mathrm{mg} / \mathrm{l})$, a ascorbic acid $(75 \mathrm{mg} / \mathrm{l})$, citric acid $(75 \mathrm{mg} / \mathrm{l})$, polyvinylpyrrolidone $(1.5 \mathrm{~g} / \mathrm{l})$, NaH2PO4. 2H2O (170 $\mathrm{mg} / \mathrm{l})$ and sucrose $(40 \mathrm{~g} / \mathrm{l})$. The $\mathrm{pH}$ of all media was adjusted to 5.6 with $0.1 \mathrm{M}$ $\mathrm{KOH}$ or $0.1 \mathrm{M} \mathrm{HCl}$ prior to addition of gelling agent. Media were dispensed either in a test tubes $(20 \times 2.5 \mathrm{~cm})$ capped with Bellco caps containing $15 \mathrm{ml}$ or in jars containing $50 \mathrm{ml}$ and autoclaved at $121^{\circ} \mathrm{C}$ and $1.1 \mathrm{Kg} / \mathrm{cm}^{2}$ for 20 $\min$.

Effect of chemical compounds (adenine hemisulfate, glutamine and glutathione) treatments on:

A-Repetitive somatic embryos cycle.

Somatic embryos clusters were cultured on MMS medium supplemented with NAA $(0.1 \mathrm{mg} / \mathrm{l})$, $\mathrm{kin}(0.5)$, activated charcoal $(1.5 \mathrm{~g} / \mathrm{l})$ and gelrite $(1.5 \mathrm{~g} / \mathrm{l})$. The superior medium resulted from the first part of this study for induce repetitive embryos cycle. In addition to different concentrations of the following chemical compounds (mg/l) treatments:-

Exp. 1: Adenine sulfate (C5H5N5. 1/2 H2SO4) [0, 40, 80 and 120].

Exp. 2: Glutamine $(0,100,200$ and 400$)$.

Exp. 3: Glutathione (0, 5, 10, 15 and 20).

Cultures were incubated at $27 \pm 1^{\circ} \mathrm{C}$ for 16 -h photoperiod with light intensity of 1500 lux using fluorescent tubes. Nine culture jars (replicates) were used. After three weeks, the number, multiplication rate, fresh weight and growth value of embryos were recorded.

\section{B- Plantlets formation and acclimatization.}

Shootlets obtained from each previous treatment were subjected individually to the MS basal medium supplemented with NAA $(0.5 \mathrm{mg} / \mathrm{l})$ in combination with IBA $(0.5 \mathrm{mg} / \mathrm{l})$, the superior combination of the selected growth regulators, tested for rooting stage in the first part of this study. In addition to the same different concentrations of the chemical compounds (mg/l) previously mentioned.

Cultures were incubated under the same embryos formation conditions except raised light intensity to 3000 Lux. Nine culture tubes (replicates) were used. After eight weeks, the number of leaves, leaf length $(\mathrm{cm})$, shootlet fresh weight $(\mathrm{g})$ and growth value were recorded.

\section{Acclimatization:}

Healthy rooted plantlets produced after two months in the rooting medium were transplanted for acclimatization procedure. Fifteen Plantlets (replicates) from each treatment were acclimatized ex vitro on soil type contain a mixture of compost + perlite $(1: 1, \mathrm{v} / \mathrm{v})$ for three months under similar conditions as previously mentioned for plantlets acclimatization in the first part of this study. Then survival percentage was recorded after 3 months. 
Hegazy, A. et al.

\section{Growth value:}

Embryo and shootlet growth values were estimated according to the equation of Ziv (1992).

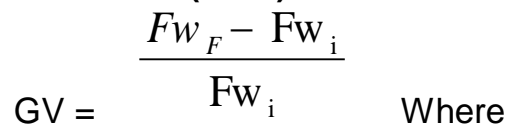

$\mathrm{GV}=$ Growth value. $\mathrm{Fwf}=$ Final explant fresh weight. Fwi $=$ Initial explant fresh weight.

\section{Statistical analysis:}

Data of all the studied experiments were statistically analyzed by one factorial randomized complete design using the SAS (1988) package. The Least Significant Difference among levels of each treatment was compared using L.S.D test at 5\%, according to Steel and Torrie (1980).

\section{RESULTS AND DISCUSSION}

\section{Effect of chemical compounds (Adenine hemisulfate, glutamine and Glutathione) concentrations during: \\ A-Repetitive somatic embryos cycle.}

During transfer of date palm plantlets cv. Malakaby from the in vitro to the ex vitro conditions, a high percentage of plantlets lost (Nasr et al., 2008). This might be due to shortage of some components in the cultured media required for micropropagated plantlets which their deficiency accompanied by insufficient supply of nutrition in the repetitive embryos stage and gradually affected embryo growth and development and subsequently resulted in severed injury in plantlets survival percentage in acclimatization. Therefore, repetitive embryos and subsequently their shootlets were subjected to the same different concentrations of some chemical compounds to clarify its effects on repetitive embryos growth and development and subsequently plantlets survival percentage during acclimatization.

\section{1-Adenine hemisulfate}

Data presented in Table (1) and Fig. (1- A) indicated that addition of adenine hemisulfate at the concentration of $40 \mathrm{mg} / \mathrm{l}$ to the repetitive embryo culture medium were recorded higher values of no. of embryos, embryos multiplication rate and growth value as well as higher significant values of fresh weight as compared with the other adenine hemisulfate concentration treatments, i.e. 0,80 , and $120 \mathrm{mg} / \mathrm{l}$. On the other hand, addition of adenine hemisulfate at the concentration of $120 \mathrm{mg} / \mathrm{l}$ gradually decreased no, of embryos, embryos multiplication rate, fresh weight and its growth value. Some scientist discussed the effect of adenine sulfate Hegazy (2003) found that the presence of adenine sulphate $(20 \mathrm{mg} / \mathrm{l})$ in modified MS medium stimulated direct embryogenesis of date palm cv. Zaghloul and Barhi. Hegazy (1992) reported that beneficial effect were obtained in explant growth and shoot proliferation of Strelitizia reginae Ait in the presence of adenine sulphate $(80 \mathrm{mg} / \mathrm{l})$ in MS medium. Also, Kaur et al. (1998) found in Acacia catechu explant that addition of adenine sulphate $(25.0 \mathrm{mg} / \mathrm{l})$, ascorbic acid $(20.0 \mathrm{mg} / \mathrm{l})$ and glutamine $(150.0 \mathrm{mg} / \mathrm{l})$ to the culture medium obtained 
maximum shoot bud induction. Moreover, Vasudevan et al. (2004) studied the effects of L-glutamine, ammonium nitrate, adenine sulphate, asparagine, ammonium succinate, potassium nitrate and sodium nitrate as the nitrogen sources on in vitro morphogenesis of cucumber (Cucumis sativus L. CV. Poinsett 76) shoot tip and found that the explants grown with $0.068 \mathrm{mM} \mathrm{L-}$ glutamine displayed the highest culture response $(74.6 \%)$ and greatest shoot number / explant (13.6) at the end of two subcultures. The explants cultured with other nitrogen sources resulted in low culture frequency and low number of shoots per explant accompanied by basal callusing and necrosis. However, the mode of action of adenine has not been fully explained. Beneficial effects from adenine addition are found in media containing both ammonium nitrate and cytokinins (George, 1993). On the other hand, Lillo (1989) studied the influence of several media components and environmental factors on shoot formation in protoplast-derived calli of Solanum tuberosum (a Rosamunda cross) and found that there was no stimulatory effect of glutamine, proline, putrescine, spermidine, spermine or adenine sulphate at 0.5 and $2 \mathrm{mM}$ were obtained.

Table (1): Effect of adenine hemisulfate concentrations on multiplicatio rate, fresh weight (g) and growth value of date palm embryos cv. Malakaby cultured in vitro for 3 weeks.

\begin{tabular}{|c|c|c|c|c|c|c|}
\hline \multirow[b]{3}{*}{ Treatment } & \multicolumn{6}{|c|}{ Growth character } \\
\hline & \multicolumn{2}{|c|}{ No. of embryos } & \multirow{2}{*}{$\begin{array}{l}\text { Multip. } \\
\text { rate }\end{array}$} & \multicolumn{2}{|c|}{ Embryo F.wt (g) } & \multirow{2}{*}{$\begin{array}{c}\text { Growth } \\
\text { value }\end{array}$} \\
\hline & Starting & Produced & & Starting & Produced & \\
\hline \multicolumn{7}{|c|}{ Adenine hemisulfate (mg/l) } \\
\hline \begin{tabular}{|c|}
0 \\
\end{tabular} & $22.67^{a}$ & $37.22^{c}$ & $1.67^{c}$ & $3.55^{a}$ & $6.55^{a b}$ & $0.86^{c}$ \\
\hline 40 & $17.22^{b}$ & $77.44^{\mathrm{a}}$ & $4.59^{a}$ & $1.59^{b}$ & $7.51^{\mathrm{a}}$ & $3.83^{a}$ \\
\hline 80 & $15.11^{\mathrm{b}}$ & $59.44^{a b}$ & $3.96^{a b}$ & $1.47^{\mathrm{b}}$ & $6.12^{b}$ & $3.28^{a b}$ \\
\hline 120 & $14.78^{b}$ & $53.00^{b}$ & $3.64^{b}$ & $1.47^{b}$ & $5.69^{b}$ & $2.89^{b}$ \\
\hline
\end{tabular}

Means within each column followed by the same letter are not significantly different at $\mathbf{P =}$ 0.05 according to the LSD test.

\section{2- Glutamine}

Data presented in Table (2) showed that addition of glutamine at the concentration of $200 \mathrm{mg} / \mathrm{l}$ to the repetitive embryo culture medium recorded the highest values of embryos multiplication rate, growth value and fresh weight as compared with the other glutamine concentration treatments, i.e. 0 , 100 , and $400 \mathrm{mg} / \mathrm{l}$. On the other hand, there is no significant difference could be noticed among all glutamine concentrations for no. of embryos while, they recorded higher significant values of no. of embryos as compared with the control. Similar results obtained by Al-Maarri and Al-Ghamdi (1995) reported that using of MS nutrient medium supplemented with $1.0 \mathrm{mg} / \mathrm{l}$ biotin, $200 \mathrm{mg} / \mathrm{l}$ glutamine, $1.0 \mathrm{mg} / \mathrm{l} \mathrm{Ca}$ - pantothenate and $1.5 \mathrm{~g} / \mathrm{l}$ activated charcoal minimized date palm explant browning. In addition, Hegazy (2003) found that the presence of glutamine $(200 \mathrm{mg} / \mathrm{l})$ in modified MS medium stimulated direct embryogenesis of date palm cv. Zaghloul and Barhi. In this concern, Steinmacher et al. (2007) reported that different positions in the shoot apex and leaf sheath of peach palm were cultured in MS medium supplemented with L Glutamine $(500 \mathrm{mg} / \mathrm{l})$ and Picloram $(0-600 \mu \mathrm{M})$ in the presence of 
Hegazy, A. et al.

activated charcoal. Formation of primary calli and embryogenic calli was obtained. Abo El-Nil (1986) studied the effects of different amino acids in the $L$ form (glycine, alanine, serine, arginine, asparagine and glutamine) and found that glutamine was the most beneficial for embryogenesis and embryogenic callus growth as it increased the growth by almost double that of control. Amino acids and amides can be added to plant media to satisfy the requirement of cultures for reduced nitrogen. Argenine increased the growth of sugar cane callus and suspension cultures (Nickell and Maretzski (1969). However, amino acids ranked in their stimulatory effect on callus growth in the following descending order: glutamine, asparagines, arginine, serine, glycine and alanine. In addition, organic nitrogen was considered as a growth-limiting factor in date palm cultures. The inclusion of glutamine decreased the culture lag phase, which might indicate that it was much more readily to be assimilated than inorganic nitrogen. Nitrogen was shown to be mainly translocated in the organic form especially glutamine and asparagine in conifer trees (Durzan and Chalupa, 1976). Conifer embryo formation is accompanied by storage protein accumulation (Roberts et al., 1990) which requires active metabolism of amino acids supported by a sufficient nitrogen supply from the culture medium. In this respect, glutamine appears as a suitable nitrogen source to support the active protein synthesis associated with somatic embryo maturation (Milfin and Lea, 1976). Khlifi and Tremblay (1995) noticed that for conifers L-glutamine should be considered as a major component of the medium during the maturation of somatic embryos. On the other hand, Lillo (1989) studied the influence of several media components and environmental factors on shoot formation in protoplast-derived calli of Solanum tuberosum (a Rosamunda cross) and found that there was no stimulatory effect of glutamine, proline, putrescine, spermidine, spermine or adenine sulphate at 0.5 and $2 \mathrm{mM}$ were obtained. Eapen and George (1990) reported that addition of amino acids such as serine, tryptophan, asparagine and glutamine to basal medium decreased the embryo germination frequency in finger millet. On the contrary, Ammirato (1993) reported that reduced added nitrogen, e.g. glutamine is generally promoting somatic embryogenesis.

Table (2): Effect of glutamine concentrations on multiplication rate, fresh weight $(\mathrm{g})$ and growth value of date palm embryos cv. Malakaby cultured in vitro for 3 weeks.

\begin{tabular}{|c|c|c|c|c|c|c|}
\hline \multirow{2}{*}{ Treatment } & \multicolumn{5}{|c|}{ Growth character } \\
\cline { 2 - 3 } & \multicolumn{2}{|c|}{ No. of embryos } & Multip. & \multicolumn{2}{|c|}{ Embryo F.wt (g) } & Growth \\
\cline { 2 - 3 } & Starting & Produced & rate & Starting & Produced & value \\
\hline Glutamine (mg/l) & & & & \\
\hline $\mathbf{0}$ & $22.67^{\mathrm{ab}}$ & $37.22^{\mathrm{b}}$ & $1.67^{\mathrm{c}}$ & $3.55^{\mathrm{a}}$ & $6.55^{\mathrm{c}}$ & $0.86^{\mathrm{c}}$ \\
\hline $\mathbf{1 0 0}$ & $24.56^{\mathrm{a}}$ & $67.22^{\mathrm{a}}$ & $2.82^{\mathrm{b}}$ & $3.33^{\mathrm{a}}$ & $9.54^{\mathrm{b}}$ & $1.86^{\mathrm{b}}$ \\
\hline $\mathbf{2 0 0}$ & $18.78^{\mathrm{b}}$ & $62.33^{\mathrm{a}}$ & $3.36^{\mathrm{a}}$ & $3.48^{\mathrm{a}}$ & $11.87^{\mathrm{a}}$ & $2.45^{\mathrm{a}}$ \\
\hline $\mathbf{4 0 0}$ & $22.67^{\mathrm{ab}}$ & $70.89^{\mathrm{a}}$ & $3.17^{\mathrm{ab}}$ & $3.52^{\mathrm{a}}$ & $11.74^{\mathrm{a}}$ & $2.34^{\mathrm{a}}$ \\
\hline
\end{tabular}

Means within each column followed by the same letter are not significantly different at $\mathbf{P}=$ 0.05 according to the LSD test. 


\section{3-Glutathione}

Data presented in Table (3) indicated that addition of glutathione at the concentration of $15 \mathrm{mg} / \mathrm{l}$ to the repetitive embryo culture medium recorded the highest significant values of no. of embryos and embryos multiplication rate as well as higher values of fresh weight and growth value as compared with the other glutathione concentration treatments, i.e. 0, 5, 10 and $20 \mathrm{mg} / \mathrm{l}$. On the other hand, there is no significant difference could be noticed among all glutathione concentration treatments in growth value. Most of the inorganic nitrogen supplied in culture media is converted by plant tissues to amino acids, which are then assimilated into proteins; it should be possible to culture plants on media on in which amino acids are the only nitrogen source. Amino acids provide plant cells with an immediately available source of nitrogen, and uptake can be much more rapid than that of inorganic nitrogen in the same medium (George, 1993). Meanwhile, Cassells and Curry (2001) reported that absence or loss of organogenic potential (recalcitrance), hyperhydricity and somaclonal variation. These phenomena affect the practical application of plant tissue culture in plant propagation and in plant genetic manipulation. Here it is hypothesized much of the variability expressed in micro plants may be, the consequence of or related to oxidative stress damage caused to the plant tissues during explant preparation and in culture due to media and environmental factors. The characteristics of these phenomena are described and causes discussed in terms of the known effects of oxidative stress on eukaryote genomes. Stasolla et al. (2004) studied the effect of reduced glutathione on morphology and gene expression of white spruce (Picea glauca) somatic embryos. Glutathione GSH increased the conversion frequency of white spruce somatic embryos without an intervening desiccation period. Examination of transcript levels has revealed that the inductive effect of GSH on plant regeneration may be related to profound alterations in the expression of genes involved in important metabolic pathways and developmental processes. Altogether this information will be valuable for ongoing studies according to the LSD test. aimed at improving somatic embryogenesis in conifers through rational manipulations of culture conditions. Belmonte et al. (2005) reported that exogenous applications of reduced glutathione $(\mathrm{GSH})$ and oxidized glutathione (GSSG) promote growth of embryogenic tissue of white spruce during a 7-day subculture period. A statistically significant increase in fresh weight as well as RNA and DNA content was observed in the presence of GSH and GSSG during the last days in culture. 
Hegazy, A. et al.

Table (3): Effect of glutathione concentrations on multiplication rate, fresh weight $(\mathrm{g})$ and growth value of date palm embryos cv. Malakaby cultured in vitro for 3 weeks.

\begin{tabular}{|c|c|c|c|c|c|c|}
\hline \multirow{3}{*}{ Treatment } & \multicolumn{6}{|c|}{ Growth character } \\
\hline & \multicolumn{2}{|c|}{ No. of embryos } & \multirow{2}{*}{$\begin{array}{l}\text { Multip. } \\
\text { rate }\end{array}$} & \multicolumn{2}{|c|}{ Embryos F.wt (g) } & \multirow{2}{*}{$\begin{array}{r}\text { Growth } \\
\text { value }\end{array}$} \\
\hline & Starting & Produced & & Starting & Produced & \\
\hline \multicolumn{7}{|c|}{ Glutathione (mg/l) } \\
\hline 0 & $22.67^{a}$ & $37.22^{c}$ & $1.67^{c}$ & $3.55^{a}$ & $6.55^{b}$ & $0.86^{b}$ \\
\hline 5 & $21.11^{a}$ & $41.44^{b c}$ & $1.99^{b c}$ & $3.51^{a}$ & $6.98^{a}$ & $1.00^{\mathrm{ab}}$ \\
\hline 10 & $22.89^{a}$ & $46.11^{b}$ & $2.11^{b}$ & $3.39^{a}$ & $7.05^{a}$ & $1.08^{\mathrm{ab}}$ \\
\hline 15 & $20.00^{a}$ & $51.44^{a}$ & $2.59^{a}$ & $3.43^{a}$ & $7.24^{a}$ & $1.10^{a}$ \\
\hline 20 & $22.78^{a}$ & $43.33^{b}$ & $1.97^{b c}$ & $3.38^{a}$ & $6.53^{b}$ & $0.93^{\mathrm{ab}}$ \\
\hline
\end{tabular}

Means within each column followed by the same letter are not significantly different at $\mathrm{P}=\mathbf{0 . 0 5}$

Effect of chemical compounds (Adenine hemisulfate, glutamine and Glutathione) treatments during:

B- Plantlets formation and acclimatization.

1- $\quad$ Adenine hemisulfate

Concerning the effects of adenine hemisulfate on plantlets formation characters in rooting medium, the obtained data (Table 4) revealed that addition of adenine hemisulfat at the concentration of $40 \mathrm{mg} / \mathrm{l}$ to culture medium had recorded the highest growth value, no. of roots and plantlets survival percentage in acclimatization as compared with the other studied adenine hemisulfate concentration treatments, i.e. 0,80 and $120 \mathrm{mg} / \mathrm{l}$. On the other hand, there is no significant difference could be noticed among all adenine hemisulfate concentrations for no. of leaves and leaf length. Results indicated that increased adenine hemisulfate concentration slightly increased shootlet fresh weight. The effect of adenine sulfate on shoot proliferation was reported by some scientists, Davis et al. (1977) on carnation, Hasegawa (1980) on rose, Reisch (1986) on grapes, Hegazy (1992) on Strelitizia reginae and Hegazy (2003) on date palm. In this regard, Mater (1986) revealed that vigorous callus growth occurred in shoot tip explants of Phoenix dactylifera $L$ offshoots cvs Barhee and Hallawi when cultured on MS medium supplemented with BA and kinetin at $2 \mathrm{mg} / \mathrm{l}$ and high levels of auxins NAA or 2, 4-D in addition to $40 \mathrm{mg} / \mathrm{l}$ adenine sulphate, $170 \mathrm{mg} / \mathrm{l} \mathrm{NaH} \mathrm{P}_{2} \mathrm{PO}_{4} \mathrm{H}_{2} \mathrm{O}, 100$ $\mathrm{mg} / \mathrm{l} \mathrm{my}$ - inositol, $0.5 \mathrm{mg} / \mathrm{l}$ thiamine $\mathrm{HCl}$. Addition of adenine sulfate to the culture medium in combination with benzyladenine was demonstrated; adenine sulfate was being converted by plant tissue into the natural cytokinin 2- isopentenyl adenine (2iP). On the other side, the enhancing effect of adenine sulfate on shoot growth was recorded by some investigators; Kaur and Kant (2000) reported that addition of adenine sulfate to Acacia catechu medium, nodal segments showed a synergistic effect on shoot bud induction and shoot quality. The mode of action of adenine has not been fully explained. Beneficial effects from adenine addition are found in media containing both ammonium nitrate and cytokinins (Goerge, 1993). Exogenous supply of adenine was salvaged and utilized for ATP and nucleic acid synthesis during the development of somatic embryos. The enlargement of the nucleotide pool is required for rapid cell proliferation and growth of the embryogenic tissue (Ashihara et al., 2001). 
Table (4): Effect of adenine hemisulfate concentrations on growth and development as well as survival percentage in acclimatization of date palm shootlet cv. Malakaby cultured in vitro for 8 weeks

\begin{tabular}{|c|c|c|c|c|c|c|c|}
\hline \multirow{3}{*}{ Treatment } & \multicolumn{7}{|c|}{ Growth character } \\
\hline & \multirow[t]{2}{*}{$\begin{array}{l}\text { No. of } \\
\text { leaves }\end{array}$} & \multirow[t]{2}{*}{$\begin{array}{l}\text { Leaf } \\
\text { length } \\
(\mathrm{cm})\end{array}$} & \multicolumn{2}{|c|}{$\begin{array}{c}\text { Shootlet } \\
\text { F.w (g) }\end{array}$} & \multirow{2}{*}{$\begin{array}{c}\text { Growth } \\
\text { value }\end{array}$} & \multirow{2}{*}{$\begin{array}{l}\text { No.of } \\
\text { roots }\end{array}$} & \multirow{2}{*}{$\begin{array}{c}\text { Survival \% } \\
\text { in } \\
\text { acclimatization }\end{array}$} \\
\hline & & & initial & Final & & & \\
\hline \multicolumn{8}{|c|}{ Adenine hemisulfate (mg/l) } \\
\hline \begin{tabular}{|l|}
$\mathbf{0}$ \\
\end{tabular} & $2.56^{a}$ & $8.44^{a}$ & $0.38^{b}$ & $1.66^{b}$ & $3.39^{a b}$ & $2.00^{b}$ & $40.00^{a b}$ \\
\hline 40 & $2.44^{a}$ & $8.11^{a}$ & $0.47^{b}$ & $1.84^{\mathrm{ab}}$ & $3.79^{a}$ & $2.78^{a}$ & $53.33^{a}$ \\
\hline 80 & $3.11^{\mathrm{a}}$ & $8.33^{a}$ & $1.09^{a}$ & $2.40^{\mathrm{a}}$ & $1.75^{b c}$ & $2.56^{a b}$ & $40.00^{\mathrm{ab}}$ \\
\hline 120 & $3.11^{a}$ & $10.11^{\mathrm{a}}$ & $0.97^{a}$ & $2.07^{a b}$ & $1.26^{c}$ & $2.00^{b}$ & $13.33^{b}$ \\
\hline
\end{tabular}

Means within each column followed by the same letter are not significantly different at $P=0.05$ according to the LSD test.

2- $\quad$ Glutamine

The results presented in Table (5) indicated that addition of glutamine at the concentration of $100 \mathrm{mg} / \mathrm{l}$ to the rooting medium had recorded the highest values of number of leaves, number of roots and the highest plantlets survival percentage in acclimatization as compared with all glutamine concentration treatments, i.e. 0,200 and $400 \mathrm{mg} / \mathrm{l}$. On the other hand, it appears that increase the level of glutamine concentration significantly decreased growth value as compared with the control. Results indicated that increased glutamine concentration slightly increased leaf length and fresh weight as compared with the control. Glutamine is an amide and changed to glutamic acid as an organic source of nitrogen. Amino acid provide plant cells with an immediately available source of nitrogen, and uptake can be much more rapid than that of in organic nitrogen in the same medium (George, 1993). Meanwhile, Kaur et al. (1998) reported that nodal explants of Acacia catechu were cultured in vitro. Maximum shoot bud development (8 to 10) from a single explant was achieved on MS medium supplemented with BA $(4.0 \mathrm{mg} / \mathrm{l})$ and NAA $(0.5 \mathrm{mg} / \mathrm{l})$. Addition of adenine sulphate $(25.0 \mathrm{mg} / \mathrm{l})$, ascorbic acid $(20.0 \mathrm{mg} / \mathrm{l})$ and glutamine $(150.0 \mathrm{mg} / \mathrm{l})$ to the culture medium recorded beneficial effect for obtained maximum shoot bud induction. The shoot buds developed into healthy and sturdy shoots on medium containing $\mathrm{BA}$ and kin at $1.0 \mathrm{mg} / \mathrm{l}$. Excised shoots were rooted on 1/4- MS salt strength with IAA (3.0 mg/l) and $1.5 \%$ sucrose to obtain plantlets. In addition, Hegazy (2003) reported that modified MS medium inclusion glutamine at the concentration of $200 \mathrm{mg} / \mathrm{l}$ enhanced repetitive somatic embryos and shoot development of date palm cvs Zaghloul and Barhi also, Vasudevan et al. (2004) studied the effects of L-glutamine, ammonium nitrate, adenine sulphate, asparagine, ammonium succinate, potassium nitrate and sodium nitrate as the nitrogen sources on in vitro morphogenesis of cucumber (Cucumis sativus L. CV. Poinsett 76). They found that shoot tip cultured on MS medium supplemented with $0.068 \mathrm{mM}$ L-glutamine displayed the highest culture response $(74.6 \%)$ and the greatest shoot number per explant (13.6) at the end of two subcultures. The explants cultured with other nitrogen sources resulted in low culture frequency and low number of shoots per 
explant accompanied by basal callusing and necrosis. Moreover, Milfin and Lea (1976) mentioned that glutamine appears as a suitable nitrogen source to support the active protein synthesis associated with somatic embryo maturation. On contrast, Eapen and George (1990) reported that addition of amino acids such as serine, tryptophan, asparagine and glutamine to basal medium decreased the embryo germination frequency in finger millet

Table (5): Effect of glutamine concentrations on growth and development as well as survival percentage in acclimatization of date palm shootlet cv. Malakaby cultured in vitro for 8 weeks.

\begin{tabular}{|c|c|c|c|c|c|c|c|}
\hline \multirow{3}{*}{ Treatment } & \multicolumn{7}{|c|}{ Growth character } \\
\hline & \multirow[t]{2}{*}{$\begin{array}{l}\text { No. of } \\
\text { leaves }\end{array}$} & \multirow[t]{2}{*}{$\begin{array}{l}\text { Leaf } \\
\text { length } \\
(\mathrm{cm})\end{array}$} & \multicolumn{2}{|c|}{$\begin{array}{c}\text { Shootlet } \\
\text { F.w (g) }\end{array}$} & \multirow{2}{*}{$\begin{array}{c}\text { Growth } \\
\text { value }\end{array}$} & \multirow{2}{*}{$\begin{array}{l}\text { No. of } \\
\text { roots }\end{array}$} & \multirow{2}{*}{$\begin{array}{c}\text { Survival } \% \\
\text { in } \\
\text { acclimatization }\end{array}$} \\
\hline & & & initial & Final & & & \\
\hline \multicolumn{8}{|c|}{ Glutamine (mg/l) } \\
\hline 0 & $2.56^{a}$ & $8.44^{c}$ & $0.38^{b}$ & $1.66^{\mathrm{b}}$ & $3.39^{a}$ & $2.00^{c}$ & $40.00^{a b}$ \\
\hline 100 & $2.90^{\mathrm{a}}$ & $9.56^{b c}$ & $0.93^{a}$ & $1.98^{a b}$ & $1.25^{b}$ & $2.78^{a}$ & $53.33^{a}$ \\
\hline 200 & $2.89^{a}$ & $13.22^{a}$ & $1.10^{\mathrm{a}}$ & $2.14^{a}$ & $1.03^{b}$ & $2.67^{a b}$ & $46.67^{a b}$ \\
\hline 400 & $2.11^{a}$ & $12.00^{a b}$ & $1.02^{a}$ & $2.02^{a b}$ & $1.01^{b}$ & $2.11^{b c}$ & $13.33^{\mathrm{b}}$ \\
\hline
\end{tabular}

Means within each column followed by the same letter are not significantly different at $\mathbf{P =}$ 0.05 according to the LSD test.

\section{3- Glutathione}

Data presented in Table (6) and Fig. (1- B, C and D) indicated that addition of glutathione at the concentration of $15 \mathrm{mg} / \mathrm{l}$ to the rooting medium recorded the highest number of leaves, fresh weight, number of roots and the highest survival percentage in acclimatization as compared with all glutathione concentration treatments, i.e. $0,5,10$ and $20 \mathrm{mg} / \mathrm{l}$. It may be due to its effect as anti-oxidant and nitrogen sources because glutathione is a peptide containing three amino acids namely glutamic, cystein and glycine. It is a source of amino acids and organic nitrogen and at the same time it works as anti-oxidant to reduce the browning phenomenon. On the other hand, there is no significant difference could be noticed among all glutathione concentrations for leaf length. Results indicated that glutathione application at low concentrations decreased growth value as compared with high levels or the control. Amino acids can be added to plant media to satisfy the requirement of cultures for reduced nitrogen, but as they are expensive to purchase, they will only be used in media for mass propagation where glutathione is a peptide containing three amino acids. Similar results were obtained by Misra and Chaturvedi (1984) reported that stem segments of Rosmarinus officinalis $\mathrm{L}$ var. genuine were cultured in vitro as a source of shoot tip on white's medium supplemented with IAA (0.1mg/l), GA3 (5.0 $\mathrm{mg} / \mathrm{l})$, ascorbic acid $(5.0 \mathrm{mg} / \mathrm{l})$ and glutathione $(20 \mathrm{mg} / \mathrm{l})$. In addition, Lucchesini et al. (1993) reported that addition of glutathione $(200 \mathrm{mg} / \mathrm{l})$ to Linsmaier and Skoog medium encouraged shoot proliferation, lateral shoot formation and rooting of of Tamarix gallica nodal explants. 
Table (6): Effect of glutathione concentrations on growth and development as well as survival percentage in acclimatization of date palm shootlet cv. Malakaby cultured in vitro for 8 weeks

\begin{tabular}{|c|c|c|c|c|c|c|c|}
\hline \multirow{3}{*}{ Treatment } & \multicolumn{7}{|c|}{ Growth character } \\
\hline & \multirow[t]{2}{*}{$\begin{array}{l}\text { No.of } \\
\text { leaves }\end{array}$} & \multirow{2}{*}{$\begin{array}{c}\text { Leaf } \\
\text { length } \\
(\mathrm{cm})\end{array}$} & \multicolumn{2}{|c|}{$\begin{array}{l}\text { Shootlet } \\
\text { F.w (g) }\end{array}$} & \multirow{2}{*}{$\begin{array}{l}\text { Growth } \\
\text { value }\end{array}$} & \multirow{2}{*}{$\begin{array}{l}\text { No. of } \\
\text { roots }\end{array}$} & \multirow{2}{*}{$\begin{array}{c}\text { Survival \% } \\
\text { in } \\
\text { acclimatization }\end{array}$} \\
\hline & & & Initial & Final & & & \\
\hline \multicolumn{8}{|c|}{ Glutathione (mg/l) } \\
\hline 0 & $2.56^{a b}$ & $8.44^{a}$ & $0.37^{b}$ & $1.66^{c}$ & $3.39^{a}$ & $2.00^{b}$ & $40.00^{a}$ \\
\hline 5 & $2.56^{\mathrm{ab}}$ & $10.11^{\mathrm{a}}$ & $0.80^{a}$ & $1.82^{b c}$ & $1.57^{\mathrm{b}}$ & $2.00^{b}$ & $46.67^{\mathrm{a}}$ \\
\hline 10 & $3.11^{\mathrm{ab}}$ & $10.67^{a}$ & $1.02^{a}$ & $2.29 \mathrm{ab}$ & $1.49^{b}$ & $2.22^{b}$ & $46.67^{a}$ \\
\hline 15 & $3.67^{\mathrm{a}}$ & $10.00^{\mathrm{a}}$ & $0.86^{a}$ & $2.79^{a}$ & $2.38^{a b}$ & $3.22^{\mathrm{a}}$ & $60.00^{\mathrm{a}}$ \\
\hline 20 & $2.22^{\mathrm{b}}$ & $9.67^{\mathrm{a}}$ & $0.77^{a}$ & $2.22^{b}$ & $2.53^{\mathrm{ab}}$ & $2.67 \mathrm{ab}$ & $60.00^{\mathrm{a}}$ \\
\hline
\end{tabular}

Means within each column followed by the same letter are not significantly different at $\mathbf{P =}$ 0.05 according to the LSD test.

Complex addenda produced amino acids (namely casein hydrolsate yeast extract - pineapple - malt extract), peptides glutathione or amide glutamine can be added to plant media to satisfy the requirement of cultures for reduced nitrogen. The response to organic nitrogen depends on the ratio of $\mathrm{NO} 3$ to NH4. Amino acids provide plant cells with an immediately available source of nitrogen and uptake can be much more rapid than that of inorganic nitrogen in the same medium. Amino acids can also provide reduced nitrogen in culture media in place of $\mathrm{NH} 4$ and as a supplement to NO3. However they are usually employed as minor addition to media containing both $\mathrm{NH} 4$ and NO3. Uptake of amino acids into cultured tissues causes a decrease in the $\mathrm{pH}$ of the medium (George, 1993). In this concern, Belmonte et al. (2003) indicated that changes in the glutathione redox state have been shown to affect plant growth and more specifically cell proliferation. Inclusion of reduced glutathione in the maintenance medium promotes the proliferation of white spruce embryogenic tissue. On the other hand, the majority of inosine was catabolized to $\mathrm{CO}_{2}$ and ureides on all monitored days under all treatments, possibly due to the low activity of inosine kinase. Thus, there is a strong correlation between the glutathione redox state and purine metabolism in the proliferation of white spruce embryogenic tissue.

\section{Conclusion}

The influence of some chemical compounds on:

A- Repetitive somatic embryos cycle.

Somatic embryo clusters cultured on MS (Murashige and Skooge, 1962) modified medium (MMS) supplemented with NAA (0.1 mg/l), kin (0.5), activated charcoal $(1.5 \mathrm{~g} / \mathrm{l})$ and gelrite $(1.5 \mathrm{~g} / \mathrm{l})$ in addition to adenine hemisulfate $(40 \mathrm{mg} / \mathrm{l})$ recorded the highest no. of embryos, multiplication rate, fresh weight and growth value. However, addition of glutamine (200 $\mathrm{mg} / \mathrm{l}$ ) recorded higher embryos multiplication rate, fresh weight and growth value. On the other hand, addition of glutathione $(15 \mathrm{mg} / \mathrm{l})$ recorded the highest significant values of number of embryos and embryos multiplication rate as well as the highest values of fresh weight and growth value. 
Hegazy, A. et al.

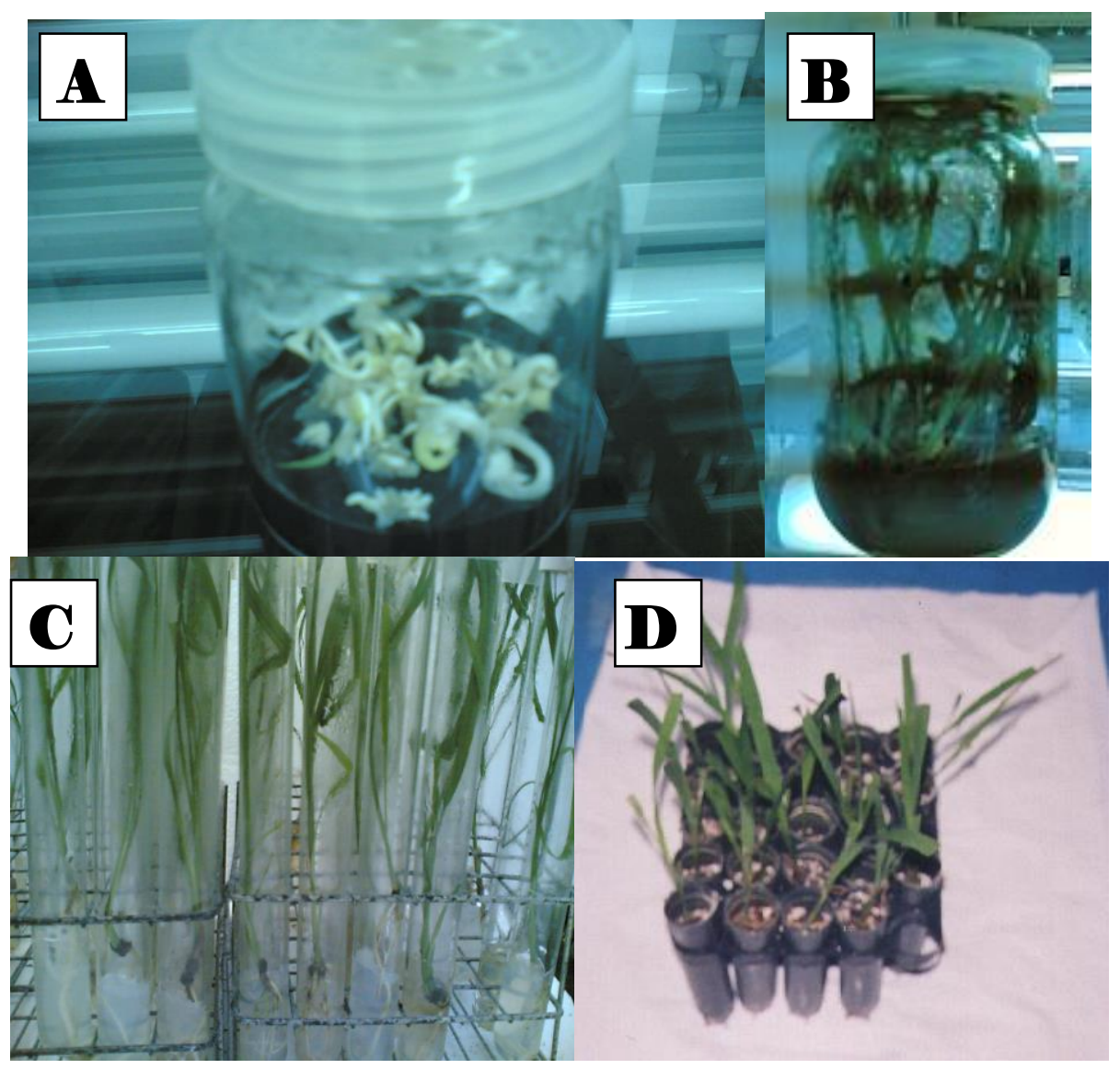

Fig (1): Developmental stages of date palm cv. Malakaby in micropropagation:

A - Repetitive somatic embryos during multiplication stage

B- Well developed shootlets during elongation stag.

C- Healthy roots of plantlets during rooting stage.

D- Plantlets in soil mixture of compost + perlite $(1: 1, \mathrm{v} / \mathrm{v})$ during acclimatization.

\section{B- Plantlets formation and acclimatization.}

Shootlets obtained from each previous treatment and subjected individually to the MS basal medium supplemented with NAA $(0.5 \mathrm{mg} / \mathrm{l})$ in combination with IBA $(0.5 \mathrm{mg} / \mathrm{l})$ in addition to adenine hemisulfate $(40 \mathrm{mg} / \mathrm{l})$ recorded the highest values of growth value, number of roots and raised plantlets survival (13.33\%) over the control in acclimatization. Moreover, addition of glutamine $(100 \mathrm{mg} / \mathrm{l})$ to the rooting medium recorded high number of leaves, number of roots and raised plantlets survival (13.33\%) over the control in acclimatization. On the other hand, addition of glutathione at the 
concentration of $15 \mathrm{mg} / \mathrm{l}$ to the rooting medium recorded the highest values of number of leaves, fresh weight, number of roots and raised plantlets survival $(20 \%)$ over the control in acclimatization.

\section{REFERENCES}

Abo El-Nil, M. M. (1986). The effect of amino acid nitrogen on growth of date palm callus. Proceeding of the Second Symposium on Date Palm. King Faisal Univ., Al-Hassa, Saudi Arabia, pp. 59-64.

Al-Maarri, K. W. and Al-Ghamdi, A. S. (1995). Effect of culturing date on in vitro micropropagation of date palm (Phoenix dactylifera L.) $\mathrm{cv}$. "Hillaly". J. of Agric. Sci., 3: 151-167.

Ammirato, P. V. (1993). Embryogenesis In: Handbook of Plant Cell Culture (Evans, D. A.; Sharp, W. R. S.; Amirato, P. V. and Amada, Y. Y., eds.) Macmillan, New York. pp. 82-123.

Ashihara, H.; Stasolla, C.; Loukanina, N. and Thorpe, T. (2001). Purine metabolisum during white spruce somatic embryo development: Salvage of adenine, adenosine and inosine. Plant Sci., 160: 647-657.

Belmonte, M. F.; Stasolla, C.; Katahira, R.; Loukanina, N.; Yeung, E. C. and Thorpe, $\mathrm{T}$.

(2005). Glutathione-induced growth of embryogenic tissue of white spruce correlates with changes in pyrimidine nucleotide metabolism. Plant Sci., 168 (3): 803-812.

Belmonte, M. F.; Stasolla, C.; Loukanina, N.; Yeung, E. C. and Thorpe, T. (2003). Glutathione modulation of purine metabolism in cultured white spruce embryogenic tissue. Plant Sci., 165 (6): 1377-1385.

Cassells, A. and Curry, R. (2001). Oxidative stress and physiological, epigenetic and genetic variability in plant tissue culture: implications for micropropagators and genetic Engineers. Plant Cell, Tissue and Organ Culture 64: 145-157.

Davis, M. J.; Baker, R. and Hanan, J. J. (1977). Clonal multiplication of carnation by micropropagation. J. Amer. Soc. Hort. Sci., 102:48-53.

Durzan, D. J. and Chalupa, V. (1976). Growth and metabolism of cells and tissue of Jack pine (Pinus banksiana) 4. Changes in amino acids in callus and in seedlings of similar genetic origin. Can. J. Bot., 54: 458462.

Eapen, S. and George, L. (1990). Influence of phytohoromones, carbohydrates, amino acids, growth supplements and antibiotics in finger millet. (Eleusine corcona). Plant Cell, Tissue and Organ Culture, 22: 87.

George, E. F. (1993). Plant Propagation by Tissue Culture. Exegetics Ltd., Edington, Wilts. BA134Q G, England.

Hasegawa, P. M. (1980). Factors affecting shoot and root initiation from cultured rose shoot tips. J. Amer. Soc. Hort. Sci., 105: 216- 220.

Hegazy, A. E. (1992).Tissue culture propagation of Strelitzia reginae Ait. plant. M. Sc. Thesis, Fac. of Agri. Al-Azhar Univ. Cairo, Egypt. 
Hegazy, A. E. (2003). Some physiological studies on date palm micropropagation through direct somatic embryogenesis. Ph. D. Thesis. Plant Physiol. Sec. Fac. of Agri. Cairo Univ. Egypt.

Kaur, K. and Kant, U. (2000). Clonal propagation of Acacia catechu Wild. By shoot tip culture. Plant Growth Regulator, 31: 143-145.

Kaur, K.; Verma, B. and Kant, U. (1998). Plants obtained from the Khair tree (Acacia catechu Willd.) using mature nodal segments. Plant Cell Reports, 17(5): 427-429.

Khlifi, S. and Tremblay, F. M. (1995). Maturation of black spruce somatic embryos. Part I. Effect of glutamine on the number and germinability of somatic embryos. Plant Cell, Tissue and Organ Culture, 41: 23-32.

Lillo, C. (1989). Effects of media components and environmental factors on shoot formation from protoplast-derived calli of Solanum tuberosum. Plant Cell, Tissue and Organ Culture, 19 (2): 103-111.

Lucchesini, M.; Mensuali-Sodi, A. and Vitagliano, C. (1993). Micropropagation of tamararix gallica from nodal explants of mature trees. Plant Cell, Tissue and Organ Culture, 35:195-197.

Mater, A. (1986). In vitro regeneration of ( Phoenix dactylifera L.). Date Palm J., 4 (2): 137-152.

Milfin, B. J. and Lea, P. (1976). The pathway of nitrogen assimilation in plants. Phytochemistry, 15: 873-885.

Misra, P. and Chaturvedi, H. C. (1984). Micropropagation of Rosmarinus officinals L. Plant Cell, Tissue and Organ Culture, 3:163-168.

Murashige, T. and Skoog, F. A. (1962). A revised medium for rapid growth and bioassays with tobacco tissue cultures. Physiol. Plant., 15: 433479.

Nasr, M. I.; Ibrahim, I. A.; Gergess, A. A.; Hegazy, A.E.and El-Bastawissy, H. $\mathrm{H}$. (2008). Micropropagation of date palm cv. Malakaby through embryogenesis 1- Effect of plant growth regulators. J. Product \& Dev., 13(3): 637- 650.

Nickell. I. G. and Maretzki, A. (1969). Growth of suspension cultures of sugar cane cells in chemically defined media. Physiol. Plant, 22: 117- 125.

Pottino, B. G. (1981). Methods in Plant Tissue Culture. Dept. of Hort., Agric., Maryland Univ., College Park, Maryland , USA, pp. 8-29.

Reisch, B. I. (1986). Influence of genotype and cytokinins on in vitro shoot proliferation of grapes. J. Amer. Soc. Hort. Sci., 111: 138-141.

Roberts, D. R.; Flinn, B. S.; Webb, D. T.; Wesbster, F. B. and Sutton, B. C. S. (1990). Abscisic acid and indole-3-butyric acid regulation of maturation and accumulation of storage proteins in somatic embryos of interior spruce. Physiol. Plant., 78: 355-360.

SAS (1988). Statistical Analysis System SAS User's Guide: Statistics SAS Institute Inc., Cary, N. S.

Stasolla, C.; Belmonte, M. F.; van Zyl, L.; Craig, D. L. Wenbin Liu, Yeung , E. C. and Sederoff, R. R. (2004). The effect of reduced glutathione on morphology and gene expression of white spruce (Picea glauca) somatic embryos. J. of Exp. Bot., 55: 695 -709. 
Steel, R. G. and Torrie, J. H. (1980). Principles and Procedures of Statistics, a Biomerical Approach. Mc Grow- Hill Book Company, New York, pp 469-517.

Steinmacher, D. A.; Krohn, N. G.; A. C. M. Dantas, A. C. M.; Stefenon, V. M.;Clement, C. R. and Guerra, M. P. (2007). Somatic embryogenesis in peach palm using the thin cell layer technique: Induction, morphohistological aspects and AFLP analysis of somaclonal variation. Annals of Botany, 100(4):699-709.

Vasudevan, A.; Selvaraj, N.; Ganapathi, A.; Kasthurirengan, S.; Ramesh Anbazhagan, V. and Manickavasagam, M. (2004). Glutamine: A Suitable Nitrogen Source for Enhanced Shoot Multiplication in Cucumis sativus L. Biol. Plant., 48(1): 125-128.

Ziv, M. (1992). The use of growth retardants for the regulation and acclimatization of in vitro plants. In: Karssen, C. M.; Van loon, L. C. and vreugdenhil, D. (eds). Progress in Plant Growth Regulation, pp. 809817.

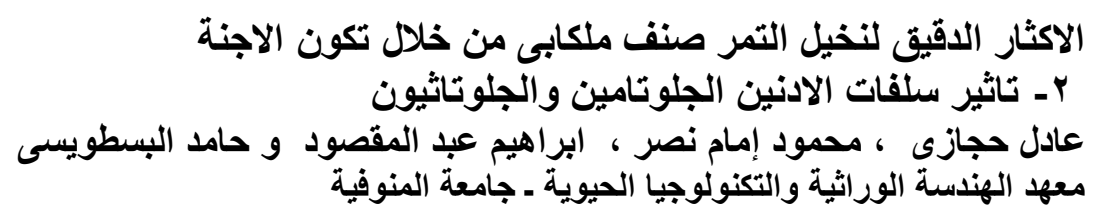

تهدف الدر اسـة إلى معرفة تـاثير اضـافة احدى المواد الكيميائيـة مثل سـلفات الادنين الجلوتـامين

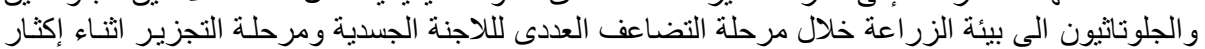

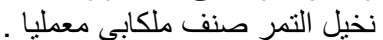

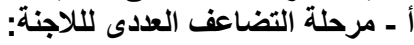

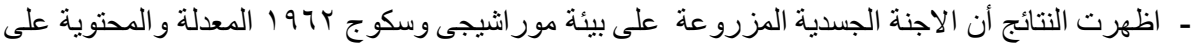

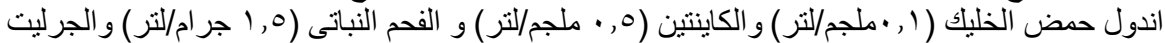

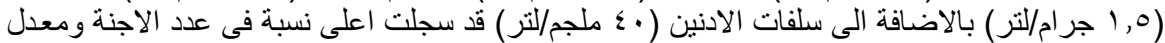

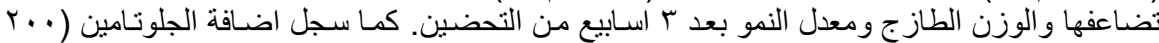

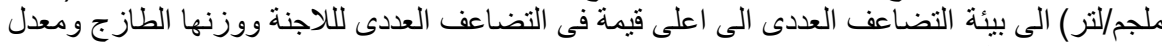

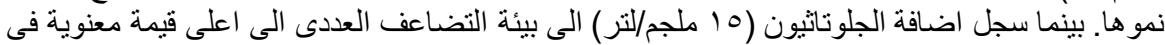

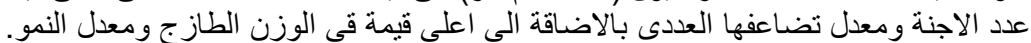
ب - مرحلة تكون التبيتات واقلمتهدها:

- الافرع الخضرية الناتجة من المرحلة السابثة تم زر اعنها على بيئة الاساس لمور اثيجى وسكوج مع اندول حمض البيوتريك (0, • ملجم/لتر) و اندول حمض الخليك (0, • ملجم/لتر) وفيتو اجار (T جم/لتر) بالاضافة الإنة

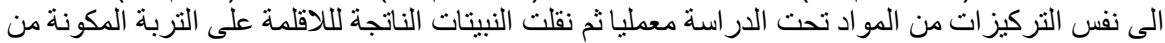

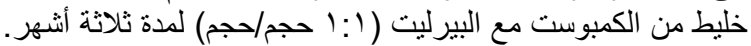

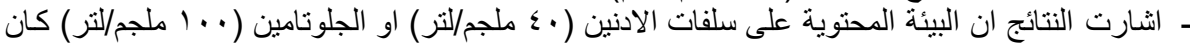

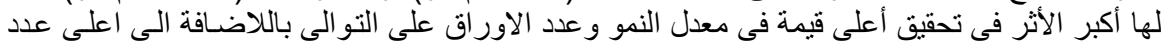

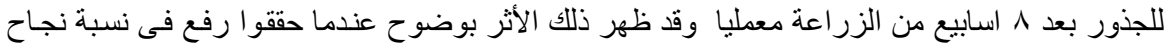

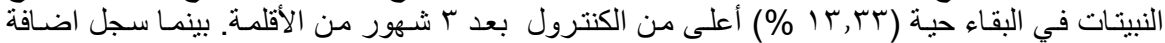

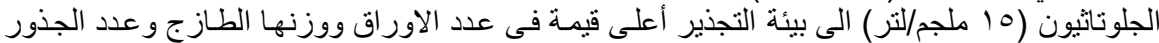

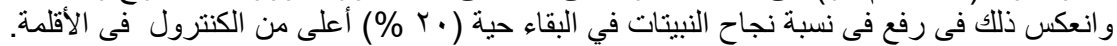

